\title{
Methyl-3-(2-hydroxy-5-nitrophenyl amino)-3-phenylpropanoate Based Colorimetric Sensor for Oxyanions
}

\author{
Venty Suryanti ${ }^{*}$, Fajar Rakhman Wibowo, and Sekar Handayani \\ Department of Chemistry, Faculty of Mathematics and Natural Sciences, Universitas Sebelas Maret, \\ Jl. Ir. Sutami 36A, Surakarta 57126, Indonesia
}

*Corresponding author:

email:venty@mipa.uns.ac.id

Received: October 10, 2018

Accepted: November 1, 2018

DOI: $10.22146 /$ ijc.39559

\begin{abstract}
A colorimetric anion sensor of methyl-3-(2-hydroxy-5-nitrophenyl amino)-3phenylpropanoate bearing $-\mathrm{OH}$ and $-\mathrm{NH}$ groups as binding sites and nitrophenyl as a signaling unit, has been successfully accomplished. The compound functioned as a colorimetric chemosensor for $\mathrm{H}_{2} \mathrm{PO}_{4}^{-}$and $\mathrm{AcO}^{-}$, in particular, the sensor showed significant naked-eye detectable color change from colorless to light yellow. In contrast, no color change was detected upon addition of other anions such as $\mathrm{SO}_{4}{ }^{2-}, \mathrm{NO}_{3}{ }^{-}$, and $\mathrm{CIO}_{4}^{-}$. The anion sensing ability of the sensor was further investigated by UV-Vis absorption spectroscopy in acetone. Characteristic UV-Vis spectra changes were revealed upon addition of $\mathrm{H}_{2} \mathrm{PO}_{4}^{-}$and $\mathrm{AcO}^{-}$.
\end{abstract}

Keywords: anion sensor; cinnamaldehyde; chemosensor; oxyanions

\section{- INTRODUCTION}

The development of colorimetric chemosensors capable of recognizing biologically important anions has received great attention. Molecules containing $\mathrm{NH}$ fragments, such as amines, amides, sulfonamides, ureas/thioureas, pyrroles/calixpyrrole, and imidazoliums groups have been widely used as binding sites for the detection of anions or toxic metal ions via hydrogen bonding interactions [1-4]. Likewise, compounds containing-OH group have been reported for colorimetric sensing of anions with successive color changes utilizing hydrogen-bonding ability of alcohol and phenolic $-\mathrm{OH}$ groups with different anions [5]. Chromogenic signaling units, such as a nitrophenyl group is frequently linked covalently to the sensor moiety. The presence of an electron-withdrawing nitro $\left(\mathrm{NO}_{2}\right)$ group enhances the acidity of the anion recognition moiety to the sensors, which enables the deprotonation of the hydrogen bond donor followed by the donation of the proton to the anions [6-9]. Suryanti et al. [10] have reported fluoride and cyanide anion sensors based on $\mathrm{N}$-acetyl glyoxylic amides, which have two $\mathrm{NH}$ groups as anion binding sites and a nitrophenyl moiety as a signaling unit. These compounds also have been reported as a receptor for anions $\mathrm{HSO}_{4}^{-}, \mathrm{Cl}^{-}, \mathrm{Br}^{-}$and $\mathrm{NO}_{3}^{-}[11]$.

Application of organic compounds as colorimetric chemosensors in biomedical and environmental sciences has been reported. A Schiff base derivative of cinnamaldehyde, 4-chloro-2-[(3-(4-(dimethylamino) phenyl)allyl-dene)amino]phenol, has been established as a colorimetric $\mathrm{Ni}^{2+}$ sensor in aqueous solution [12]. A cinnamaldehyde derivative, methyl-3-(2-hydroxy-5nitrophenyl amino)-3-phenylpropanoate 4 has been prepared by a three-step synthetic reaction from cinnamaldehyde (Scheme 1) [13]. Cinnamaldehyde 1 was oxidized into cinnamic acid 2, followed by esterification reaction with methanol to give methyl cinnamate 3 . The addition reaction of methyl cinnamate with 2-amino-4-nitrophenol produced compound 4, which comprises amine and hydroxyl groups as anion binding sites and nitrophenyl moiety as a signaling unit. This compound was expected to bind to anions via strong hydrogen bond functionalities on amine and/or hydroxyl moiety. In this work, we report the colorimetric sensing of compound 4 towards a variety of oxyanions, such as $\mathrm{H}_{2} \mathrm{PO}_{4}^{-}, \mathrm{AcO}^{-}, \mathrm{SO}_{4}{ }^{2-}, \mathrm{NO}_{3}^{-}$, and $\mathrm{ClO}_{4}^{-}$. 


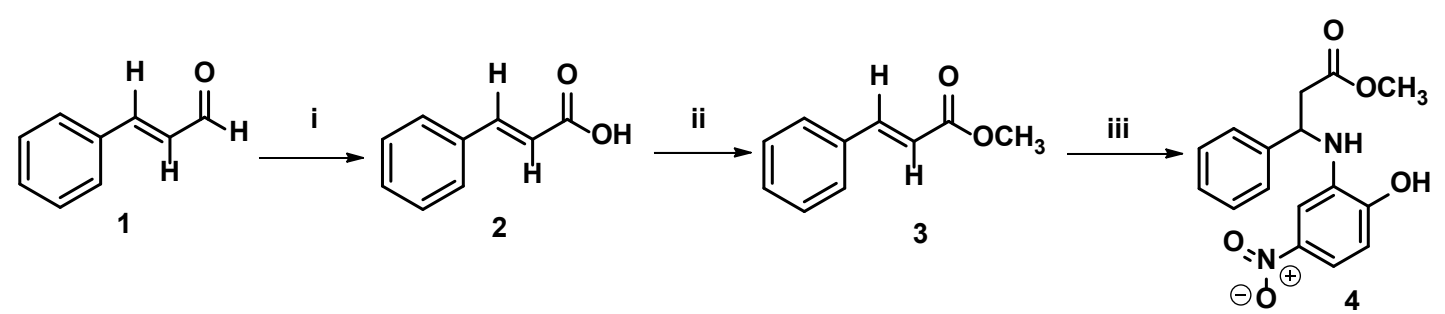

Scheme 1. Reagents and reactions: (i) $\left(\mathrm{C}_{2} \mathrm{H}_{5}\right)_{2} \mathrm{O}, \mathrm{H}_{2} \mathrm{O}$, Polysorbate $20, \mathrm{CrO}_{3}, 6$ h, r.t. (ii) $\mathrm{CH}_{3} \mathrm{OH}$, sat. $\mathrm{HCl}$, reflux, 6 h. (iii) $\mathrm{CH}_{2} \mathrm{Cl}_{2}$, reflux, $48 \mathrm{~h}$

\section{- EXPERIMENTAL SECTION}

\section{Materials}

All anions in the form of tetrabutylammonium salts were purchased from Sigma-Aldrich Chemical Company and used without further purification. All reagents and solvents employed were of analytical grade and also used without further purification.

\section{Instrumentation}

The UV-Vis spectra were recorded on a UV-Vis Shimadzu Lambda 25 spectrophotometer at room temperature. The ${ }^{1} \mathrm{H}$ NMR spectra were measured with an Agilent VNMR $400 \mathrm{MHz}$ instrument at $25^{\circ} \mathrm{C}$. The ESI mass spectrum was recorded on a Waters LCT XE ESITOF.

\section{Procedure}

\section{Synthesis of Methyl-3-(2-hydroxy-5-nitrophenylamino) -3-phenylpropanoate (4)}

The synthesis of compound 4 was accomplished based on previously published procedures using cinnamaldehyde as a starting material [13]. The first step was the oxidation reaction of cinnamaldehyde 1 with chromium trioxide $\left(\mathrm{CrO}_{3}\right)$ in diethyl ether and water in the presence of polysorbate 20 as phase transfer catalyst to give cinnamic acid 2 . The reaction was then followed by esterification of the acid with methanol under reflux for $6 \mathrm{~h}$ in the presence of concentrated $\mathrm{HCl}$. The last step was the reaction between 2-amino-4-nitrophenol with the ester 3 in dichloromethane under reflux for $48 \mathrm{~h}$ to give the compound 4. This procedure gave compound 4 in $65 \%$ yields and m.p. $80{ }^{\circ} \mathrm{C} .{ }^{1} \mathrm{H}$ NMR $\left(400 \mathrm{MHz}, \mathrm{CD}_{3} \mathrm{OD}\right): \delta$ $3.62\left(\mathrm{~s}, \mathrm{OCH}_{3}, 3 \mathrm{H}\right), 6.51$ (d, Ar- $\left.\mathrm{CHC} \underline{\mathrm{H}}, J=16 \mathrm{~Hz}, 2 \mathrm{H}\right), 6.75$ (m, Ar- $\underline{\mathrm{H}} \underline{\mathrm{CH}}, J=8.7 \mathrm{~Hz}, 1 \mathrm{H}$ ), 7.37 (dd, 3 x Ar-H, $J=10.9$,
$8.1 \mathrm{~Hz}, 3 \mathrm{H}), 7.50(\mathrm{dd}, J=10.9,8.1 \mathrm{~Hz}, 1 \mathrm{H}), 7.56(\mathrm{~m}, 3 \mathrm{x}$ Ar-H, 3H), 7.67(m, Ar-H, 1H). MS (ESI-TOF) m/z calculated for $\mathrm{C}_{16} \mathrm{H}_{16} \mathrm{~N}_{2} \mathrm{O}_{5}(\mathrm{M}-\mathrm{H})^{-}$315.3007. Found 315.3002 .

\section{Anion binding studies}

A solution of compound 4 in acetone with a concentration of $10^{-5} \mathrm{M}$ was added with $10^{-3} \mathrm{M}$ oxyanion (as tetrabutylammonium salts) solution with variations amount of moles equivalent to compound 4 (0-10 moles equivalent). The resulting product was then analyzed by naked eye and characterization using UV-Vis spectroscopy.

\section{Computational studies}

The molecular structure of compound $\mathbf{4}$ which has the most stable conformation was reacted with $\mathrm{AcO}^{-}$or $\mathrm{H}_{2} \mathrm{PO}_{4}^{-}$ions. The interaction that occurs was calculated using ONIOM with the method HF/basis set 6-311G (d, p) as a low layer and the DFT/cc-PVDZ method as a high layer. The result was a log archive which was used for UV-Vis characterization.

\section{Statistical Analysis}

Experimental results were performed in triplicate, and the data were presented as mean $\pm \mathrm{SD}$. The results were compared by one-way ANOVA. The difference was considered as statistically significant if $\mathrm{p} \leq 0.05$.

\section{- RESULTS AND DISCUSSION}

Since protic solvents will compete with anions in forming hydrogen-bonding interaction with the sensor, the colorimetric sensing ability of compound 4 was performed in aprotic solvents, such as acetone. The anions were added as their tetrabutylammonium salts to compound 4 solutions $\left(1 \times 10^{-5} \mathrm{M}\right)$. The visible color 


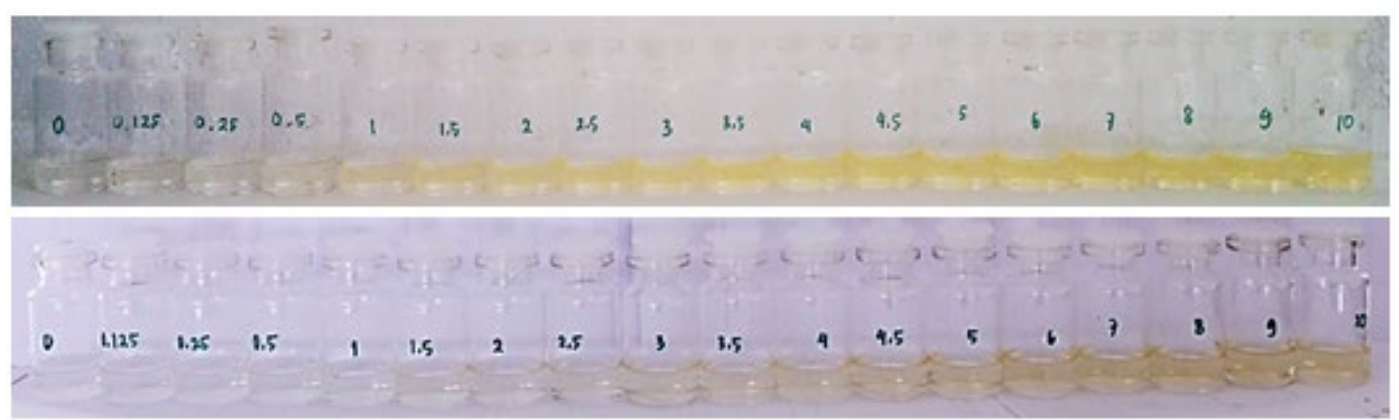

Fig 1. Color changes observed for compound 4 in acetone upon addition of the anions as TBA salts: $\mathrm{H}_{2} \mathrm{PO}_{4}^{-}$(upper) and $\mathrm{AcO}^{-}$(lower)

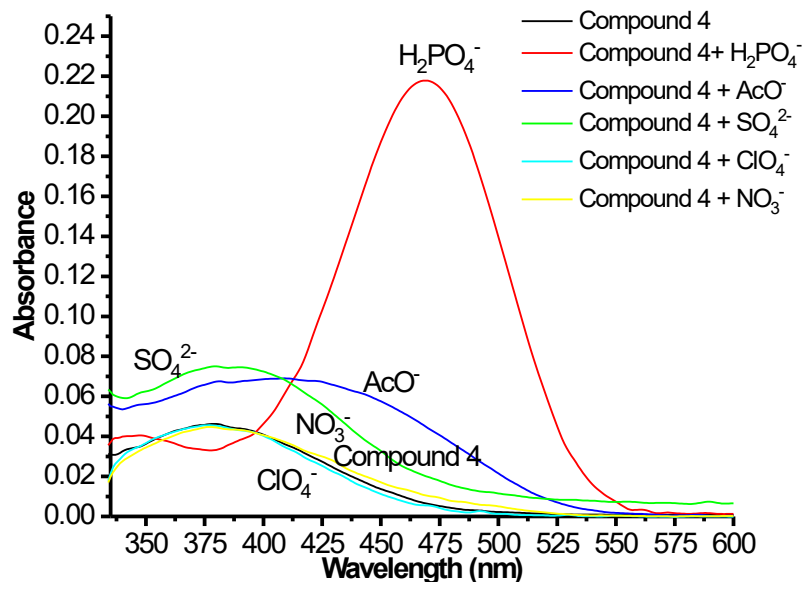

Fig 2. The absorption spectra of compound $4\left(1 \times 10^{-5} \mathrm{M}\right)$ in acetone solution upon addition of 4 eq. of anions as TBA salts, such as $\mathrm{H}_{2} \mathrm{PO}_{4}^{-}, \mathrm{AcO}^{-}, \mathrm{SO}_{4}{ }^{2-}, \mathrm{NO}_{3}{ }^{-}$, and $\mathrm{ClO}_{4}{ }^{-}$

and the UV-Vis spectral changes towards anions were studied. Since peaks of protons from $-\mathrm{OH}$ and $-\mathrm{NH}$ groups did not appear in ${ }^{1} \mathrm{H}$ NMR spectra, the colorimetric sensing ability of sensor $\mathbf{4}$ was not monitored by ${ }^{1} \mathrm{H}$ NMR Spectroscopy.

\section{Visual Color Change Observation}

A solution of compound 4 changed from colorless to faint yellow upon the addition of 1 eq. of $\mathrm{H}_{2} \mathrm{PO}_{4}{ }^{-}$or 2.0 eq. of $\mathrm{AcO}^{-}$. The coloration of the solution was intensified with increasing anions concentration. The color changes of compound 4 upon the addition of $\mathrm{H}_{2} \mathrm{PO}_{4}^{-}$or $\mathrm{AcO}^{-}$ions were detected by the naked eye. The representative photographs showing the color change of solutions of compound 4 by $\mathrm{H}_{2} \mathrm{PO}_{4}^{-}$or $\mathrm{AcO}^{-}$ions are shown in Fig. 1. Under similar experimental conditions, the addition of

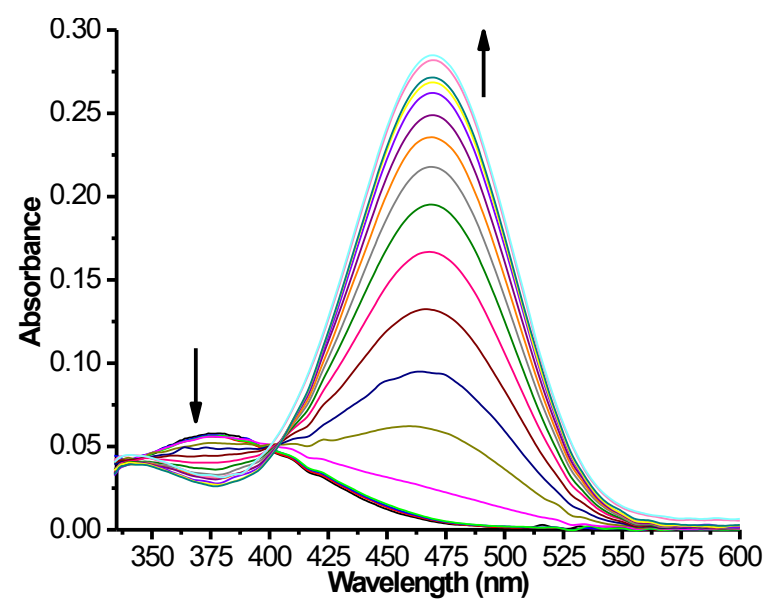

Fig 3. The absorption spectra of compound $4\left(1 \times 10^{-5} \mathrm{M}\right)$ in acetone solution upon the addition 0-10 eq. of tetrabutylammonium dihydrogen phosphate

$\mathrm{SO}_{4}{ }^{2-}, \mathrm{NO}_{3}{ }^{-}$or $\mathrm{ClO}_{4}{ }^{-}$to the solution of compound $4 \mathrm{did}$ not exhibit any naked-eye detectable color change.

\section{Anion Recognition Studies by UV-Vis Spectroscopy and Computational Methods}

As preliminary studies, the spectroscopic behaviors of compound $\mathbf{4}$ in acetone were investigated upon addition 4 eq. of various anions, such as $\mathrm{H}_{2} \mathrm{PO}_{4}^{-}$, $\mathrm{AcO}^{-}, \mathrm{SO}_{4}{ }^{2-}, \mathrm{NO}_{3}^{-}$, and $\mathrm{CIO}_{4}^{-}$. One characteristic absorption peak for UV-Vis spectra of compound $\mathbf{4}$ was observed at $379 \mathrm{~nm}$ in the absence of anions. As shown in Fig. 2, compound 4 reveals insignificant perturbation upon addition of 4 eq. of $\mathrm{NO}_{3}{ }^{-}$and $\mathrm{ClO}_{4}{ }^{-}$. In contrast, significant UV-Vis absorption spectra changes were noticed in the presence of $\mathrm{H}_{2} \mathrm{PO}_{4}{ }^{-}$where the absorption band at $379 \mathrm{~nm}$ disappeared, and a new absorption band 


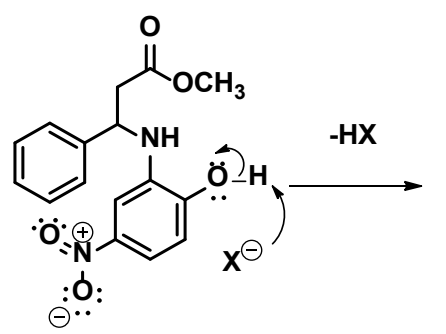<smiles>COC(=O)CC(Nc1cccc([N+](=O)[O-])c1)c1ccccc1[O-]</smiles><smiles>COC(=O)CC(NC1=CC(=O)C=CC1=O)c1ccc([N+](=O)[O-])cc1</smiles>

Scheme 2. Resonance structure of the deprotonated form of compound 4

appeared at $475 \mathrm{~nm}$. In the presence of $\mathrm{AcO}^{-}$, the absorption peak at $379 \mathrm{~nm}$ moved to $456 \mathrm{~nm}$. Meanwhile, the UV-Vis absorption spectra increased upon addition of 4 eq. of $\mathrm{SO}_{4}{ }^{2-}$. The sensing abilities of the sensor towards $\mathrm{H}_{2} \mathrm{PO}_{4}^{-}, \mathrm{AcO}^{-}$and $\mathrm{SO}_{4}{ }^{2-}$ were then studied by UV-Vis titration experiments.

The UV-Vis absorption spectra changes were obtained upon addition of increasing amount of $\mathrm{H}_{2} \mathrm{PO}_{4}^{-}$ ions to the acetone solution of sensor 4 (Fig. 3). The absorption peak at $379 \mathrm{~nm}$ gradually decreases its intensity, and a strong absorption peak gradually appeared at $469 \mathrm{~nm}$. These new absorption peaks existed upon addition of 1 eq. of $\mathrm{H}_{2} \mathrm{PO}_{4}^{-}$. Furthermore, the color change from colorless to faint yellow could be detected by naked eye for the solution of compound 4 along with the addition of $\mathrm{H}_{2} \mathrm{PO}_{4}^{-}$ions. A clear isosbestic point at 401 and $402 \mathrm{~nm}$ was observed during the titration process between the compound 4 and $\mathrm{H}_{2} \mathrm{PO}_{4}^{-}$ion, respectively. The development of new bands and the presence of a clear isosbestic point can be explained by initial hydrogen bond formation between $\mathrm{H}_{2} \mathrm{PO}_{4}^{-}$and $\mathrm{NH}$ and $\mathrm{OH}$ groups followed by deprotonation which subsequent intramolecular charge-transfer (ICT) transitions within the whole structure of the sensor 4 (Fig. 4 and Scheme 2) [14-15].

A similar phenomenon of UV-Vis absorption was also observed upon addition of $\mathrm{AcO}^{-}$to a solution of compound 4 (Fig. 5). As the concentration of $\mathrm{AcO}^{-}$was increased, the absorption peak at $379 \mathrm{~nm}$ disappeared while a new absorption peak at $456 \mathrm{~nm}$ developed. This new absorption peak appeared upon addition of 2 eq. of $\mathrm{AcO}^{-}$. These spectral characteristics were also accompanied by a visual color change of the solution from colorless to faint yellow upon addition of $\mathrm{AcO}^{-}$. These
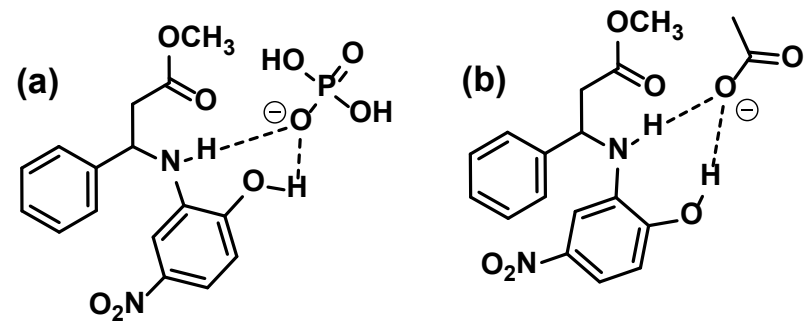

Fig 4. Proposed initial hydrogen bonding interactions between compound 4 and $\mathrm{H}_{2} \mathrm{PO}_{4}^{-}$(a) or $\mathrm{AcO}^{-}$(b)

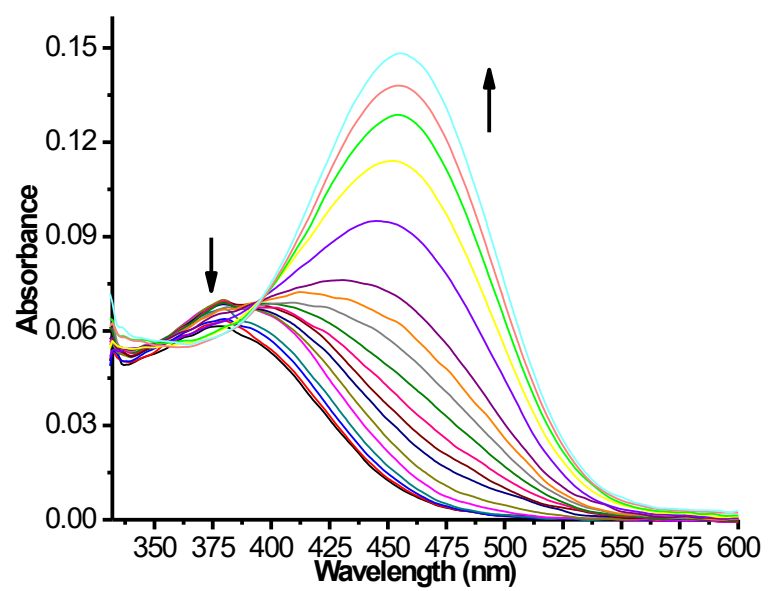

Fig 5. The absorption spectra of compound $4\left(1 \times 10^{-5} \mathrm{M}\right)$ in acetone solution upon the addition 0-10 eq. of tetrabutylammonium acetate

results suggest that $\mathrm{AcO}^{-}$initially formed hydrogen bonding interactions with sensor 4 , followed by deprotonation of compound $\mathbf{4}$ upon further addition of $\mathrm{AcO}^{-}$with the subsequent ICT transitions within the entire structure of the compound 4 (Fig. 4 and Scheme 2) [16]. However, an approximate isosbestic point at $392 \mathrm{~nm}$ was observed during the titration process, indicating that deprotonation was not complete and the hydrogenbonded complex and the deprotonated compound $\mathbf{4}$ were both existed. 


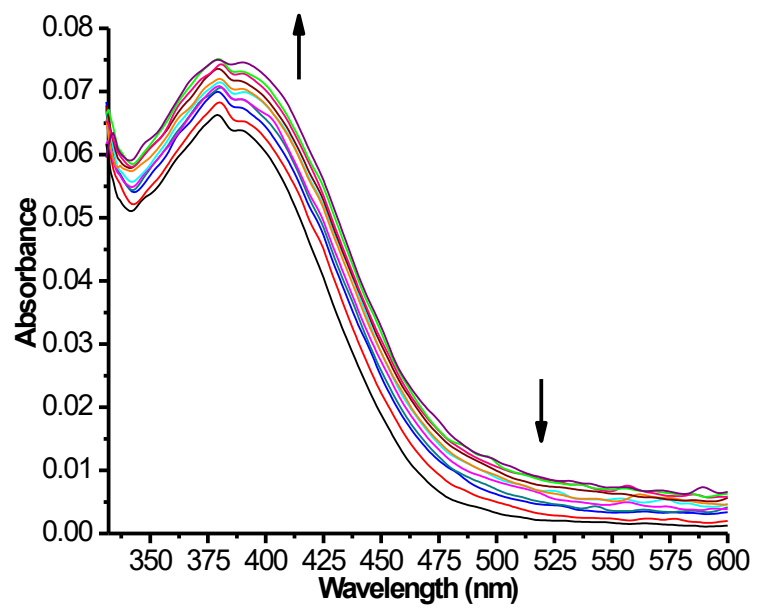

Fig 6. The absorption spectra of compound $4\left(1 \times 10^{-5} \mathrm{M}\right)$ in acetone solution upon the addition 0-10 eq. of tetrabutylammonium sulphate

The possibility of deprotonation occurs in $-\mathrm{OH}$ proton because the electronegativity of oxygen atom is greater than that of nitrogen atom so that the partial positive charge of hydrogen atom will be more easily removed from the oxygen atom compared to the nitrogen atom. The $-\mathrm{OH}$ proton (the partial positive charge) interacts strongly with oxyanion (a negative charge). In addition, $-\mathrm{OH}$ group also facilitates the withdrawal of electrons by $\mathrm{NO}_{2}$ groups. Consequently, the hydrogen atom is easily separated from the oxygen atom. The loss of the $-\mathrm{OH}$ proton causes electron delocalization in the structure of compound 4 to a more stable form (Fig. 4).

Under similar experimental conditions, increasing of UV-Vis absorption spectra were found in the addition of less basic anion such as $\mathrm{SO}_{4}{ }^{2-}$ (Fig. 6). However no changes in absorption peaks of UV-Vis spectra. These findings implied that $\mathrm{SO}_{4}{ }^{2-}$ formed weak hydrogen bonding interactions with compound 4 , which was not able to pursue deprotonation of compound 4 . Hence, no visible color changes were observed. On the contrary, the addition of weakly basic anions such as $\mathrm{NO}_{2}{ }^{-}$and $\mathrm{ClO}_{4}{ }^{-}$ did not show any noticeable spectra or color changes which suggest no interaction or complexation of these anions with compound 4.

Computational data revealed that the UV-Vis spectrum of compound $\mathbf{4}$ gave an absorption peak in the wavelength of $306.35 \mathrm{~nm}$. The interaction of compound 4 with anions causes a shift in the wavelength to 544.34 and
$560.11 \mathrm{~nm}$ for $\mathrm{AcO}^{-}$and $\mathrm{H}_{2} \mathrm{PO}_{4}^{-}$, respectively. The UV$V$ is spectra resulting from the interaction of compounds 4 with $\mathrm{AcO}^{-}$and $\mathrm{H}_{2} \mathrm{PO}_{4}^{-}$oxyanion caused a longer (bathochromic) wavelength shift. This indicates that an electronic structure of compound $\mathbf{4}$ changes due to conformational changes due to the addition of $\mathrm{AcO}^{-}$and $\mathrm{H}_{2} \mathrm{PO}_{4}^{-}$to receptor compounds. The UV-Vis spectra shift since the presence of oxyanion is related to the formation of hydrogen bonds and/or deprotonation between the ions with the protons of $-\mathrm{NH}$ and $-\mathrm{OH}$ groups which causes a decrease in energy for electronic transition through delocalization.

In the experiment data, the interaction of receptor compounds with anions causes a shift in the wavelength to 410 and $475 \mathrm{~nm}$ for $\mathrm{AcO}^{-}$and $\mathrm{H}_{2} \mathrm{PO}_{4}^{-}$, respectively. The wavelength difference occurred in the experiment with the theory from computational data was related to the difference in oxyanion used. The wavelengths that have been produced experimentally and the theory have the corresponding results where the addition of $\mathrm{AcO}^{-}$ and $\mathrm{H}_{2} \mathrm{PO}_{4}^{-}$oxyanions can shift the wavelength towards the visible area.

Compounds 4 were selective for $\mathrm{H}_{2} \mathrm{PO}_{4}^{-}$and $\mathrm{AcO}^{-}$ over other oxyanions such as $\mathrm{SO}_{4}{ }^{2-}, \mathrm{NO}_{3}{ }^{-}$, and $\mathrm{ClO}_{4}^{-}$. This can be explained by basicity and/or the hydrogen bonding ability of the anions. Among the tested oxyanions, the order of basicity of oxyanions was $\mathrm{AcO}^{-}$ $>\mathrm{H}_{2} \mathrm{PO}_{4}^{-}>\mathrm{SO}_{4}{ }^{2-}>\mathrm{NO}_{3}{ }^{-}>\mathrm{ClO}_{4}{ }^{-}$. As the basicity and hydrogen bonding ability of $\mathrm{H}_{2} \mathrm{PO}_{4}^{-}$and $\mathrm{AcO}^{-}$are higher than that of the rest of the tested anions, they provide strong hydrogen bonding interactions and undergo deprotonation reactions with compound 4 [1718]. Meanwhile, $\mathrm{SO}_{4}{ }^{2-}$ established weak hydrogen bonding interactions with compound 4 , which was not able to undertake deprotonation reactions. Conversely, the weakly basic anions such as $\mathrm{NO}_{3}{ }^{-}$and $\mathrm{ClO}_{4}{ }^{-}$were unable to establish hydrogen bonding interactions nor deprotonation reactions.

Interestingly, the deprotonation of compound $\mathbf{4}$ took place at higher concentrations of $\mathrm{AcO}^{-}$than that of $\mathrm{H}_{2} \mathrm{PO}_{4}^{-}$. This was an unexpected result as the $\mathrm{AcO}^{-}$has higher basicity than that of $\mathrm{H}_{2} \mathrm{PO}_{4}^{-}$which should have considered greater hydrogen bond donor capacity to the 
$\mathrm{NH}$ and/or $\mathrm{OH}$ groups. The selectivity of the anions toward sensor 4 can be explained on the degree of shape complementarity between the host and anionic guests. Thus, sensor 4 employs better affinities for $\mathrm{H}_{2} \mathrm{PO}_{4}{ }^{-}$with tetrahedral geometry than that of $\mathrm{AcO}^{-}$with planar $\mathrm{Y}$ shaped geometry [19-20].

\section{- CONCLUSION}

We have developed a novel colorimetric sensor 4 based on an organic compound from cinnamaldehyde containing $\mathrm{NH}$ and $\mathrm{OH}$ groups as binding sites and a nitrophenyl moiety as a signaling unit. Compound $\mathbf{4}$ was selective for $\mathrm{H}_{2} \mathrm{PO}_{4}^{-}$and $\mathrm{AcO}^{-}$over other examined oxyanions. Both anions exhibited hydrogen bonding interactions with the compound $\mathbf{4}$ and induced deprotonation of the sensor 4. The subsequent intramolecular charge-transfer transitions of the compound 4 then occurred resulting in the visible color and the UV-Vis spectra changes. However, the sensor 4 showed better affinities for tetrahedral geometry of $\mathrm{H}_{2} \mathrm{PO}_{4}^{-}$than that of Y-shaped geometry of $\mathrm{AcO}^{-}$. These results showed that the organic compound based cinnamaldehyde derivative could provide a very important application in anion recognition and sensing of chemical, environmental and biological systems.

\section{- ACKNOWLEDGMENTS}

The authors acknowledge their thanks to Universitas Sebelas Maret and Ministry of Research, Technology and Higher Education Indonesia for the financial support of this research.

\section{- REFERENCES}

[1] Esteban-Gómez, D., Fabbrizzi, L., and Licchelli, M., 2005 Why, on interaction of urea-based receptors with fluoride, beautiful colors develop, J. Org. Chem., 70 (14), 5717-5720.

[2] Amendola, V., Esteban-Gomez, D., Fabbrizzi, L., and Licchelli, M., 2006 What anions do to N-H containing receptors, Acc. Chem. Res., 39 (5), 343353.

[3] Ahmad, I., Sharma, A., and Ghosh, T., 2012, Selective colorimetric sensing of $\mathrm{CN}^{-}$by dihydropyrazol-3-ol derivative in $\mathrm{CH}_{3} \mathrm{CN} / \mathrm{H}_{2} \mathrm{O}$ medium, Supramol. Chem., 24 (4), 221-227.

[4] Erdemir, S., Kocyigit, O., Alici, O., and Malkondu, S., 2013, Naked-eye detection of $\mathrm{F}^{-}$ions by two novel colorimetric receptors, Tetrahedron Lett., 54 (7), 613-617.

[5] Gale, P.A., 2010, Anion receptor chemistry: Highlights from 2008 and 2009, Chem. Soc. Rev., 39 (10), 3746-3771.

[6] Gale, P.A., Navakhun, K., Camiolo, S., Light, M.E., and Hursthouse, M.B., 2002, Anion-anion assembly: A new class of anionic supramolecular polymer containing 3,4-dichloro-2,5-diamidosubstituted pyrrole anion dimers, J. Am. Chem. Soc., 124 (38), 11228-11229.

[7] Gunnlaugsson, T., Kruger, P.E., Jensen, P., Pfeffer, F.M., and Hussey, G.M., 2003, Simple naphthalimide based anion sensors: deprotonation induced colour changes and $\mathrm{CO}_{2}$ fixation, Tetrahedron Lett., 44 (49), 8909-8913.

[8] Boiocchi, M., Del Boca, L., Gómez, D.E., Fabbrizzi, L., Licchelli, M., and Monzani, E., 2004, Nature of urea-fluoride interaction: incipient and definitive proton transfer, J. Am. Chem. Soc., 126 (50), 1650716514.

[9] Park, J.J., Kim, Y.H., Kim, C., and Kang, J., 2011, Fine tuning of receptor polarity for the development of selective naked eye anion receptor, Tetrahedron Lett., 52 (26), 3361-3366.

[10] Suryanti, V., Bhadbhade, M., Chawla, H.M., Howe, E., Thordarson, P., Black, D.S., and Kumar, N., 2014, Novel colorimetric anion sensors based on $N$ acetylglyoxylic amides containing nitrophenyl signalling units, Spectrochim. Acta, Part A, 121, 662-669.

[11] Suryanti, V., Bhadbhade, M., Black, D.S., and Kumar, N., 2017, $\mathrm{N}$-acetylglyoxylic amide bearing a nitrophenyl group as anion receptors: NMR and Xray investigations on anion binding and selectivity, J. Mol. Struct., 1146, 571-576.

[12] Peralta-Domínguez, D., Rodríguez, M., RamosOrtíz, G., Maldonado, J.L., Meneses-Nava, M.A., Barbosa-García, O., Santillan, R., and Farfán, N., 
2015, A Schiff base derivative from cinnamaldehyde for colorimetric detection of $\mathrm{Ni}^{2+}$ in water, Sens. Actuators, B, 207, 511-517.

[13] Suryanti, V., Wibowo, F.R., Pranoto, Isnaeni, S.R., Sari, M.R.K., and Handayani, S., 2016, Addition reaction of methyl cinnamate with 2-amino-4nitrophenol, IOP Conf. Ser. Mater. Sci. Eng., 107, 012062.

[14] Lin, T.P., Chen, C.Y., Wen, Y.S., and Sun, S.S., 2007, Synthesis, photophysical, and anion-sensing properties of quinoxalinebis(sulfonamide) functionalized receptors and their metal complexes, Inorg. Chem., 46 (22), 9201-9212.

[15] Lv, Y., Wei, W., and Xie, Y., 2015, A BODIPYphenol-based sensor for selectively recognizing three basic anions, J. Chil. Chem. Soc., 60 (1), 2843-2846.

[16] Yen, Y.P., and Ho, K.W., 2006, Synthesis of colorimetric receptor for dicarboxylate anions: A unique color change for malonate, Tetrahedron Lett.,
47 (7), 1193-1196.

[17] Amendola, V., Boiocchi, M., Fabbrizzi, L., and Palchetti, A., 2005, Anion receptors containing $\mathrm{NH}$ binding sites: Hydrogen-bond formation or neat proton transfer?, Chem. Eur. J., 11 (1), 120-127.

[18] Amendola, V., Bergamaschi, G., Boiocchi, M., Fabbrizzi, L., and Milani, M., 2010, The squaramide versus urea contest for anion recognition, Chem. Eur. J., 16 (14), 4368-4380.

[19] Jia, C., Wu, B., Li, S., Yang, Z., Zhao, Q., Liang, J., Li, Q.S., and Yang, X.J., 2010, A fully complementary, high-affinity receptor for phosphate and sulfate based on an acyclic tris(urea) scaffold, Chem. Commun., 46 (29), 5376-5378.

[20] Makuc, D., Hiscock, J.R., Light, M.E., Gale, P.A., and Plavec, J., 2011, NMR studies of anion-induced conformational changes in diindolylureas and diindolylthioureas, Beilstein J. Org. Chem., 7, 12051214. 